\title{
CLINICAL AND MOLECULAR CHARACTERISTICS OF A BRAZILIAN FAMILY WITH SPINOCEREBELLAR ATAXIA TYPE 1
}

\author{
ISCIA LOPES-CENDES*, CARLOSE. STEINER **, ISABEL SILVEIRA***,

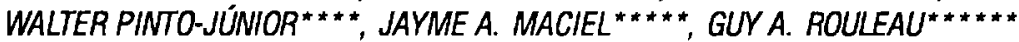

\begin{abstract}
The spinocerebellar ataxias (SCAs) are a clinically and genetically heterogencous group of late onset neurodegenerative disorders. To date, seven different genes causing autosomal dominant SCA have been mapped:SCA1, SCA2, Machado-Joseph disease (MJD)/SCA3, SCA4, SCA5, SCA7 and dentatorubropallidoluysian atrophy (DRPLA). Expansions of an unstable trinucleotide CAG repeat cause three of these disorders: SCAI, $M J D / S C A 3$ and DRPLA. We studied one Brazilian family segregating an autosomal dominant type of SCA. A total of ten individuals were examined and tested for the presence of the SCAI, MJD and DRPLA mutations. Three individuals, one male and two fernales, were considered affected based on neurological examination; ages at onset were: 32,36 and 41 years. The first complaint in all three patients was gait ataxia which progressed slowly over the years. Six individuals showed one allele containing an expanded CAG repeat in the SCAl gene. The mean size of the expanded allele was $48.2 \mathrm{CAG}$ units. Instability of the expanded CAG tract was seen in the two transmissions that were observed in this family. In both occasions there was a contraction of the CAG tract. Our study demonstrates that SCA1 occurs in the Brazilian population. In addition, our results stress the importance of molecular studies in the confirmation of diagnosis and for pre-symptomatic testing in SCAs.
\end{abstract}

KEY WORDS: neurodegenerative disease, spinocerebellar ataxia, trinucleotide expansion.

Características clínicas e moleculares de uma família brasileira com ataxia espinocerebelar tipo 1

RESUMO - As ataxias espinocerebelares (AECs) fazem parte de um grupo de doenças neurodegenerativas que apresentam grande heterogeneidade clínica e genética. Existem até o momento sete genes mapeados responsáveis pelas AECs de transmissão autossômica dominante: SCA1, SCA2, doença de Machado-Joseph (DMJ) ou SCA3, SCA4, SCAS, SCA7 e atrofia dentatorubropalidoluisiana ( $A D R P L)$. Uma expansão de um trinucletídeo CAG foi identificada como a mutação responsável na $S C A 1, D M J$ e $A D R P L$. Estudamos uma família brasileira com uma forma autossômica dominante de AEC. Dez indivíduos foram examinados e amostras de sangue foram colhidas para os estudos moleculares das mutações causadoras da SCA1, DMJ e ADRPL. Três membros da família foram considerados clinicamente afetados, um indivíduo do sexo masculino e dois do sexo feminino. A idade de início dos sintomas foi 32, 36 e 41 anos. Ataxia da marcha, lentamente progressiva, foi a primeira manifestaçāo da doença nos três pacientes. Em seis indivíduos os estudos moleculares mostraram um alelo com expansão da sequência CAG contida no gene SCAI. O tamanho médio do alelo CAG expandido foi 48,2 unidades. $O$ alelo $S C A l$ expandido apresentou instabilidade nas duas trasmissōes observadas, nas quais ocorreram contraçōes de uma e de seis unidades CAG. O nosso estudo mostra que a SCAl ocorre na população brasileira. Além disso, os nossos resultados reforçam a importância dos estudos moleculares na confirmą̧ão diagnóstica e no diagnóstico pré-sintomático de pacientes com AEC.

PALAVRAS-CHAVE: doença neurodegnerativa, ataxia espinocerebelar, expansāo de trinucleotídeo.

* MD, Centre for Research in Neuroscience, McGill University and The Montreal General Hospital Research Institute, Montreal (CRN-MGHRI), Quebec, Canada; MD, Departamento de Genética Médica, da Faculdade de Ciências Médicas da Universidade Estadual de Campinas (FCM-UNICAMP), Campinas, São Paulo, Brazil, *** Pharm D, CRN-MGHRI; **** MD, PhD, Departamento de Genética Médica, FCM-UNICAMP; ***** MD, PhD, Departamento de Neurologia, FCM-UNICAMP; ***** Md, PhD, CRN-MGHRI. Aceite: 10-maio-1996.

Dr. Iscia Lopes-Cendes - Centre for Research in Neuroscience, The Montreal General Hospital Research Institute, Room L12-132 - 1650 Cedar Ave.-Montreal, Quebec, Canada H3G 1A4. FAX 155149348265 . E-mail: bke6@musicb.mcgill.ca 
The spinocerebellar ataxias (SCAs) are a heterogeneous group of adult onset neurodegenerative disorders characterized clinically by progressive cerebellar ataxia with variable associated features including ophthalmoplegia, dysarthria, dysphagia, pyramidal and extrapyramidal signs. Genetically, these disorders can be divided into: autosomal recessive, autosomal dominant, and isolated cases. To date, seven different loci causing autosomal dominant SCA are mapped: the SCAl locus on chromosome $6 \mathrm{p}^{12,39}$, the SCA2 locus on chromosome $12 \mathrm{q}^{7,16,21}$, the Machado-Joseph disease (MJD)/ $S C A 3$ locus on chromosome $14 \mathrm{q}^{30,33,36,38}$, the SCA4 locus on chromosome $16 \mathrm{q}^{6}$, the $S C A 5$ locus on the centromeric region of chromosome $11^{25}$, the $S C A 7$ locus on chromosome $3 \mathrm{p}^{2,9}$ and the dentatorubropallidoluysian atrophy (DRPLA) locus on chromosome $12 \mathrm{p}^{15}$. However, there are families that do not map to any of these locations ${ }^{17,37}$. The mutations causing three of these disorders, $S C A 1^{22}, M J D / S C A 3^{3,14,19}$ and $D R P L A^{15}$, have been identified. In all three instances affected individuals have an expansion of a trinucleotide CAG repeat in the coding region of the disease genes.

The identification of these three mutations responsible for SCA allows us to recognize families that segregate $S C A 1, M J D$ or $D R P L A$, thus providing means for accurate classification and diagnosis of these disorders. We undertook this study in order to determine whether a mutation in one of the SCA genes identified (SCA1, MJD and DRPLA) was responsible for the disease in a Brazilian family with autosomal dominant SCA.

\section{SUBJECTS}

A total of ten individuals were examined and bloods were collected for molecular studies. All individuals in this family were enrolled in a genetic counseling program prior to the study and received supportive counseling throughout the clinical evaluation and molecular testing.

\section{METHODS}

\section{DNA isolation}

Genomic DNA was isolated from peripheral blood leukocytes using standard manual techniques ${ }^{28}$.

PCR analysir

The published primer sequences: Repl and Rep229, MJD52 and MJD25 $5^{14}$, and B37 CAG repeat primer sequences ${ }^{15}$ were used for detection of the $S C A 1, M J D$, and $D R P L A$ mutations, respectively. Polymerase chain reaction (PCR) was carried out in a total volume of $12.5 \mu$, with $100 \mathrm{ng}$ of genomic DNA; $1 \mu \mathrm{M}$ of each primer; $200 \mu \mathrm{M}$ of dGTP, dCTP, dTTP and dATP; 1 unit of Taq polymerase and $2 \%$ formamide. Samples were processed through 30 to 32 cycles of denaturation, annealing, and clongation at different temperatures, as described previously 32 . PCR products were separated in $6 \%$ polyacrylamide gels. Gels were transferred into Hybond N+ nylon membranes and hybridized with a $\alpha{ }^{-32} \mathrm{P} 3$ '-end labelled (CAG) ${ }_{15}$ probe. Allele sizes were determined by comparing migration relative to an M13 sequencing ladder. Patients previously identified with the SCA $1, M J D$ and DRPLA mutations were used as positive controls in all analyses.

As previously reported for the $S C A 1$ gene, normal alleles have a size range of 6 to 39 CAG repeats, while affected alleles have 40 to 81 CAG repeats ${ }^{4,8,13,20,23}$. The normal $D R P L A$ allele ranges from 8 to 25 CAGs, while in affected $D R P L A$ alleles 54 to 68 CAGs are found ${ }^{15}$. In normal individuals the $M J D$ gene contains 12 to 37 CAG repeats, while in affected patients the repeat number ranges from 62 to $84^{3,19}$.

\section{RESULTS}

This Brazilian family is probably of Italian origin; however Portuguese background cannot be completely excluded. Of the ten family members examined there were three clinically affected individuals, one male and two females. The Figure shows the reduced pedigree of the family and the Table summarizes the demographic and molecular information obtained in the study.

Individual II- 1 began to develop gait ataxia at age 41 , neurological examination after 5 years of disease onset showed moderate gait ataxia, incoordination in upper limbs, globally increased deep tendon reflexes and pyramidal signs. A CT scan at the time of examination revealed cerebellar atrophy. Individual II-4 began to have gait ataxia at age 32 . The disease has progressed slowly and 
Table. Demographic data and molecular characteristics of ten individuals studied in the Brazilian family segregating the SCAl mutation.

\begin{tabular}{ccccc}
\hline $\begin{array}{c}\text { Pedigree } \\
\text { Number }\end{array}$ & $\begin{array}{c}\text { Age at Examination } \\
\text { (years) }\end{array}$ & $\begin{array}{c}\text { Age at Onset } \\
\text { (years) }\end{array}$ & $\begin{array}{c}\text { Normal Allele } \\
\text { (CAG units) }\end{array}$ & $\begin{array}{c}\text { Expanded Allele } \\
\text { (CAG units) }\end{array}$ \\
\hline II-1 & 46 & 41 & 31 & 50 \\
II-4 & 36 & 32 & 30 & 51 \\
II-5 & 37 & 36 & 30 & 48 \\
III-1 & 23 & - & 32 & 49 \\
II-2 & 24 & - & 30 & 47 \\
III-8 & 26 & - & 32 & 44 \\
II-3 & 43 & - & $31 / 32$ & - \\
III-2 & 19 & - & $31 / 33$ & - \\
II-6 & 47 & - & $31 / 32$ & - \\
II-7 & 40 & - & $31 / 32$ & - \\
\hline
\end{tabular}

Note: Double entries for normal alleles indicate the sizes of the two normal alleles found.

A dash (-) in the expanded allele column indicates that no abnormal allele was found.

after 4 years of disease evolution he presented mild gait ataxia, incoordination in upper limbs and increased knee jerk. A CT scan was considered normal. Individual II-5 started symptoms about one year before examination at age 36 and showed only mild gait ataxia. Other clinical findings including cognitive impairment, optic atrophy, ophthalmoplegia, dysphagia, dystonia and Parkinsonian features were not seen in this family. All remaining individuals examined were clinically normal.

Six individuals had an abnormal CAG repeat in the SCAl gene (Figure), three males and three females. The number of repeats in the expanded allele varied from 44 to $51 \mathrm{CAG}$ units, with a mean of 48.2. Mild instability of the CAG tract was seen in the two transmissions that could be documented in this family. In both occasions there was a contraction of the CAG tract, of one and six CAG units. By contrast, the normal alleles were transmitted in a mendelian fashion and varied from 30 to 33 CAG repeats (Figure).

The appearance of the normal and the expanded CAG repeats in the SCAI gene varied markedly. All the normal alleles had a single strong band distinctively seen in the autoradiographs, whereas the expanded alleles showed several bands (Figure).

The ten individuals genotyped in this family had CAG repeats of normal size in the $M J D$ and DRPLA genes (data not shown).

\section{DISCUSSION}

The classification of the autosomal dominant SCAs has been difficult due to variability and overlapping in clinical characteristics and pathological presentation. It is not uncommon to find affected individuals, in the same family, with a wide variety of symptoms ${ }^{10}$. It is now generally accepted that the controversies involving diagnosis and classification of this group of disorders will only be solved when the molecular aspects are clarified ${ }^{26}$. With the cloning of the $S C A 1, M J D$ and DRPLA genes and the characterization of the respective mutations an accurate diagnosis can now be performed, even in small families or single affected individuals. This will result in a better estimate of the prevalence of these disorders, as well as provide more detailed clinical, pathological and molecular information that will improve our understanding of these group of diseases. 

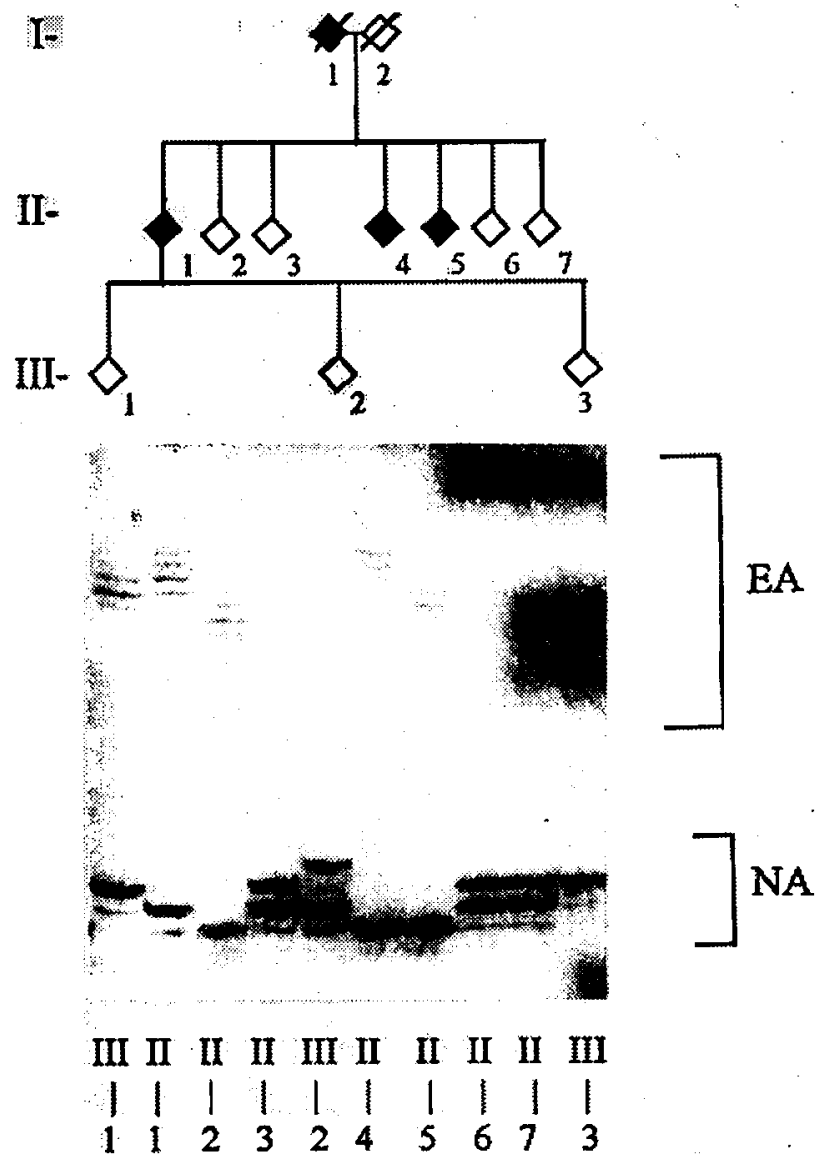

Top panel: Reduced pedigree of the Brazilian family carrying the SCAI mutation. Blackened symbols represent clinically affected individuals. Diagonal lines indicate deceased individuals. Bottom panel: Analysis of PCR products containing the expanded CAG repeat at the SCAI locus. Genomic DNA was amplified using primers Rep 1 and Rep 2. PCR products were analyzed on 6\% polyacrylamide gels. Normal alleles (NA) had sizes varying from 30 to 33 CAG units and expanded alleles (EA) varied from 44 to 51 CAGs.

$W^{32}$ and others ${ }^{24}$ have determined the frequency of the three different SCAs for which direct molecular diagnosis is available: $S C A 1, M J D$ and $D R P L A$. Families of different geographic and ethnic origins have been reported with the SCAI mutation; however, SCAI seems to occur more frequently in certain ethnic groups such as Italians and Eastern (EuropeansRanum et al. ${ }^{24}$, Silveira et al. ${ }^{32}$, and Lopes-Cendes unpublished results]. In Southern Italy a cluster of SCA1 families has been described sharing the same haplotype for markers closely linked to the SCAI locus, which suggests 
a common origin of these families ${ }^{12}$. Therefore, it is not surprising to find SCA 1 families in Brazil particularly in regions of strong Italian immigration. The family described in this paper is most likely of Italian background.

Clinical variability is usually present in SCA1, even within the same family. There has been no description of any clinical feature that is specific for SCA1 patients ${ }^{8,20,34}$. Symptoms usually begin in the third and fourth decade of life and are characterized by gait ataxia, dysarthria, and ophthalmoplegia ${ }^{\star}$. Limb ataxia is typically less severe than gait ataxia. In the early stages, eye movements appear to be full and the saccadic velocities are relatively preserved ${ }^{34}$. The disorder gradually progresses and patients become bedridden after 10 to 20 years of disease evolution. In the later stages of the disease, distal areflexia occurs, and dysphagia develops leading to frequent choking spells and aspiration pneumonia. Some degree of increased tone as well as dystonic movement may occur late in the course of the disease. Dementia has not been observed in genetically proven SCA1 families; although mild cognitive decline may occur in the advanced stages of the disease ${ }^{34}$. Infrequent signs include optic atrophy and Parkinsonian features ${ }^{8,20}$. One of the largest SCA1 families studied, the Schut kindred, shows remarkable heterogeneity in disease presentation, with cases starting in the first or second decades of life and progressing rapidly, as well as patients with onset after the fourth decade presenting a mild disease ${ }^{2 y}$. The Brazilian SCA1 family reported here is relatively small and does not permit extensive clinical correlations; however it seems that the disease presentation has been very similar in the three clinically affected individuals, and with no specific associated features such as: slow eye movements, extrapyramidal features, peripheral signs, retinal degeneration and myoclonus, which are more frequently found in SCA2, MJD, SCA4, SCA7 and DRPLA patients, respectively 2,6,15,16,14,25,26. Small families with patients presenting a short evolution of the disease, such as the Brazilian SCA1 pedigree, represent a very difficult problem for the clinical differential diagnosis. We believe that diagnostic questions in SCA patients can only be solved with molecular testing.

The observation that in one single family, the disease has a tendency for a progressive earlier onset with increased severity in younger generations has intrigued researchers in the field of SCAs for a long time. This phenomenon, called anticipation, is observed in other neurodegenerative disorders, such as: Huntington disease, Kennedy disease, MJD and DRPLA ${ }^{35}$. All of which are caused by an expansion of a trinucleotide CAG. It has been observed that translation of the mutant protein actually occurs and that the CAG stretch codes for a polyglutamine tract at the protein level ${ }^{11,31}$. These observations suggest a toxic gain of function by the proteins containing an expanded glutamine tract ${ }^{11.27}$. In addition, the observed inverse correlation between the repeat size and age at onset of the disease and the tendency of an overall increase in the CAG repeat size in successive generations ${ }^{13,23}$, indicate that this toxic effect is proportional to the length of the polyglutamine tract. Therefore, offering a possible molecular explanation for the phenomenon of anticipation observed in these neurodegenerative disorders.

The molecular characteristics of the expanded CAG repeat found in this family are similar to those reported in other SCA1 families ${ }^{8,13,20,22}$. We observed mild instability during transmission of the expanded CAG tract, suggesting gametic mosaicism. In addition, the observation of multiple bands for the expanded allele, that were seen in the autoradiographs, indicates the presence of somatic mosaicism, with different cells containing different lengths of the CAG repeat.

In SCA 1 families an inverse correlation between the size of the CAG repeat and the age at onset of the disease has been observed ${ }^{13,20,22,23}$; however this correlation is not perfect, only about $66 \%$ of variability in age at onset can be attributed to the length of the CAG repeat in these SCA1 patients. This suggests that there are factors other than the repeat size involved in the determination of the disease phenotype. Therefore, the size of the CAG repeat is not a good predictor of age at onset in SCA1. Although the CAG tract has a tendency for expansion in successive generations ${ }^{13.23}$, anticipation cannot be always observed, since contractions, as seen in the Brazilian SCA1 family, also occur. 
Confirmation or exclusion of diagnosis can be accomplished in almost all pre-symptomatic or suspected cases of SCA1, specially if affected family members are also tested. The availability of such highly sensitive and specific test for a late onset disorder has raised several questions about ethic and legal aspects of molecular testing in at risk individuals $\mathrm{s}^{1}$. This emphasizes the importance of a multidiciplinary supportive counseling program that should be available for all individuals undergoing this type of molecular testing.

Acknowledgments - The authors would like to thank the family members who participated in this project. This work was supported by: the joint Program FRSQ-ACAF (Fonds de la Recherche en Santé du Québec and Association Canadienne de l'Ataxie de Friedreich), the N1H (grant NS 31687) and the Network of Centres of Excellence (Canadian Genetic Disease Network). Dr. I.L.C. is supported by a fellowship from the Savoy Foundation. I.S. is recipient of a scholarship from JNICT (Junta Nacional de Investigação Cientifica e Tecnológica), Portugal and Dr. G.A.R. is supported by the Medical Research Council of Canada and the Fonds de la Recherche en Santé du Québec.

\section{REFERENCES}

1. Benjamin CM, Adam S, Wiggins S, Theilmann JL, Copley TT, Bloch M, Squitieri F, McKellin W, Cox S, Brown SA, Kremer HPH, Burgess M, Meshino W, Summers A, Mcgregor D, Buchanan J, Greenberg C, Carson N, Ives E, Frecker M, Welch JP, Fuller A, Rosenblatt D, Miller S, Dufresne S, Roy M, Andermann E, Prevost C, Khalifa M, Girard K, Taylor S, Hunter A, Goldsmith C, Whelan D, Eisenberg D, Soltan H, Kane J, Shokeir MHK, Gibson A, Cardwell S, Bumforth S, Grover S, Suchowersky O, Klimek M, Garber T, Gardner HA, MacLeod P, Hayden MR. Proceed with care: direct predictive testing for Huntington disease. Am J Hum Genet 1994:55:606-617.

2. Benomar A, Krols L, Stevanin G, Cancel G, LeGern E, David G, Ouhabi H, Martin J-J, Durr A, Zaim A, Ravise N, Busque C, Penet C, Van Regemorter N, Weissenbach J, Yahyaoui M, Chkili T, Agid Y, Van Broeckhoven C, Brice A. The gene for autosomal dominant cerebellar ataxia with pigmentary macular dystrophy maps to chromosome 3p12-p21.1 Nature Genet 1995; 10:84-88.

3. Cancel G, Abbas N, Stevanin G, Durs A, Chneiwejss H, Néri C, Duyckaerts C, Penet C, Cunn HM, Agid Y, Brice A. Marked phenotypic heterogeneity associated with expansion of a CAG repeat sequence at the spinocerebellar ataxia 3/MachadoJoseph disease locus. Am J Hum Genet 1995;57:809-816.

4. Chong SS, McCall AE, Cota J, Subramony SH, Orr HT, Hughes MR, Zoghbi HY. Gametic and somatic tissue-specific heterogeneity of the expanded SCA I CAG repeat in spinocerebellar ataxia type 1. Nature Genet 1995;10:344-350.

5. Currier RD, Subramony SH. Is it possible to differentiate clinicully the ataxias ? Paper presented at the 3rd International Workshop on Muchado-Joseph disease, Furnas, São Miguel, Azores, April 7-9, 1994.

6. Gardner K, Alderson K, Galster B, Kaplan C, Leppert M, Ptacek L. Autosomal dominant spinocerebellar attuxia: clinical description of a distinct hereditary ataxia and genetic localization to chromosome 16 (SCA4) in a Utah kindred [Abstract]. Neurology 1994; 44 (Suppl 2):92IS.

7. Gispert S, Twells R, Orozeo G, Brice A, Weber J, Heredero L, Schewfler K, Riley B, Allotey R, Nothers C, Hillermann R, Lunkes A, Khati C. Stevanini G, Hemandez A, Magarino C, Klockgether T, Durr A, Chneiweiss H, Enczmann J, Farral M, Beckmann J, Mullan M, Wernet P, Agid Y, Freund H-J, Williamson R, Auburger G and Chanberluin S. Chromosomal assignment of the second locus for autosomal dominant cerebellar ataxia (SCA2) to chromosome 12q23-24.1. Nature Genet 1993;4:295-299.

8. Giunti P, Sweeney MG, Spadaro M, Jodice C, Novelletto A, Malaspina P, Frontali M, Harding AE. The trinucleotide repeat expansion on chromosome 6p (SCA I) in autosomal dominant cerebellar utaxias. Brain 1994;1 17:645-649.

9. Gouw LG, Kilplan CD, Haines JH, Digre KB, Rutledge SL, Matilla A, Leppert M, Zoghbi HY, Ptácek LJ. Retinul degeneration characterizes a spinocerebellar ataxia mapping to chromosome 3p. Nature Genet 1995; 10:89-93.

10. Harding AE. Clinical features and classification of inherited ataxias. In Harding AE, Deufel $T$ (eds). Inherited ataxias. New York: Raven Press, Adv Neurol 1993:61:1-14.

11. Housman D. Gain of glutumines, gain of function ? Nature Genet 1995;10:3-6.

12. Jodice C, Frontali M, Persichetti F, Novelletto A, Pandolfo M, Spuradaro M, Giunti P, Schinaja G, Lulli P, Malaspina P, Plasmati R, Tola R, Antonelli A, Donato SD, Morocutti C, Weissenbach J, Cann HM, Terrenato L. The gene for spinal cerebellar ataxia l (SCAl) is flanked by two closely linked highly polymorphic microsutellite loci. Hum Molec Genet 1993;2:1383-1387.

13. Jodice C, Mul uspina P, Persichetni F, Novelletto A, Spadaro M, Giunti P, Morocutti C, Tertenuto L, Harding AE, Frontali M. Effect of trinucleotide repeat length and parental sex on phenotypic variation in spinocerebellar ataxia 1 . Am J Hum Genet 1994;54:959-965.

14. Kawaguchi $Y$, Okamoto T, Taniwaki $M$, Aizawa M, Inoue M, Katayama S, Kawakami H, Nakamura S, Nishimura M, Akiguchi l, Kimura J, Narumiya S, Kakizuka A. CAG expansions in a novel gene for Machado-Joseph disease at chromosome 14q32.1. Nuture Genet 1994;8:221-228.

15. Koide R, Ikeuchi T, Onodera $O$, Tanaka $H$, Igarashi S, Endo K, Takahashi H, Kondo R, Ishikawa A, Hayashi T, Saito M, Tomoda A, Miike T, Naito H, lkuta F, Tsuji S. Unstable expansion of CAG repent in hereditary dentatorubrul-pallidoluysian atrophy (DRPLA). Nature Genet 1994;6:9-13.

16. Lopes-Cendes I, Andermann E, Atrig E, Cendes F, Bosch S, Wagner M, Gerstenbrand F, Andermann F, Rouleau GA. Confirmation of the SCA-2 locus as an alternative locus for dominantly inherited spinocerebellar ataxias and refinement of the candidate region. Am J Hum Genet 1994;54:774-781. 
17. Lopes-Cendes I, Andermann E, Rouleau GA. Evidence for the existence of a fourth dominantly inherited spinocerebellar ataxia locus. Genomics 1994;21:270-274.

18. Lopes-Cendes I, Silveira I, Maciel P, Gaspar C, Radyany J, Chitayat D, Babul R, Stewart J, Dolliver M, Robitaille Y, Rouleau G, Sequeiros J. Limits of clinical assessment in the accurate diagnosis of Machado-Joseph disease, 1996 [Submitted for publication!.

19. Maciel P, Gaspar C, DeStefano A, Silveira I, Coutinho P, Radvany J, Dawson DM, Sudarsky L, Guimurāes J, Loureiro JEL, Nezarati MM, Corwin LI, Lopes-Cendes I, Rooke K, Rosenberg R, Macleod P, Funer LA, Sequeiros J, Rouleau GA. Correlation between CAG repeat length and clinical features in Machado-Joseph disease. Am J Hum Genet 1995;57:54-61.

20. Matilla T, Volpini V, Genís D, Rosell J, Corral J, Dávalos A, Molins A, Estivill X. Presymptomatic unalysis of spinocerebellar ataxia type 1 (SCA I) via the expansion of the SCA I CAG-repeat in a large pedigree displaying anticipation and parental male bias. Hum Molec Genet 1993;2:2123-2128.

21. Nechiporuk A, Lopes-Cendes I, Nechiporuk T, Starkman S, Frederick T, Andermann E, Rouleau GA, Weissenbach JS, Kort E, Pulst SM. Genetic mapping of the spinocerebellar ataxia type 2 gene on human chromosome 12. Neurology 1996 [in press].

22. Orr HT, Chung M, Banfi S, Kwiatkowski TJ-J, Servadio A, Beaudet AL, McCall AE, Duvick LA, Ranum LPW, Zoghbi HY. Expansion of an unstable trinucleotide CAG repeat in spinocerebellar ataxia type 1. Nature Genet 1993;4:221-226.

23. Ranum LPW, Chung M, Banfi S, Bryer A, Schut LJ, Ramesar R, Duvick LA, McCall A, Subramony SH, Goldfarb L, Gomez C, Sandkuijl LA, Orr HT, Zoghbi HY. Molecular and clinical correlations in spinocerebellar ataxia type 1: evidence for familial effects on the age at onset. Am J Hum Genet 1994;55:244-252.

24. Ranum LPW, Lundgren JK, Schut LJ, Ahrens MJ, Perlman JA, Bird TD, Gomez C, Or HY, Spinocerebellar ataxia type 1 and Machado-Joseph disease: incidence of CAG expansions among adult-onset ataxia putients from 311 families with dominant, recessive or sporadic ataxia. Am J Hum Genet 1995;57:603-608.

25. Ranum LPW, Schut LJ, Lundgren JK, Orr HT, Livingston DM. Spinocerebellar ataxia type 5 in a family descended from the grandparents of President Lincoln maps to chromosome 11. Nature Genet 1994; 8:280-284.

26. Rosenberg RN. Autosomal dominant cerebellar phenotypes: the genotype has settled the issue. Neurology 1995;45:1-5.

27. Ross CA. When more is less: pathogenesis of glutamine repeat neurodegenerative diseases. Neuron 1995;15:493-496.

28. Sambrook J, Fritsch EF, Manjatis T. Molecular cloning: a laboratory manual. New York: Cold Spring Harbor Laboratory Press, 1989.

29. Schut JW. Hereditary ataxia: clinical study through six generations. Arch Neurol Psych 150;63:535-568.

30. Sequeiros J, Silveira I, Maciel P, Coutinho P, Manaia A, Gaspar C, Burlet P, Loureiro L, Guimarües J, Tanaka H, Takjyama Y, Sakamoto H, Nishizawa M, Nomura Y, Segawa M, Tsuji S, Melki J, Munnich A. Genetic linkage studies of Machado-Joseph disease with chromosome 14q STRPs in 16 Portuguese-Azorean kindreds. Genomics 1994;21:645-648.

31. Servadio A, Koshy B, Armstrong D, Antalffy B, On HT, Zoghbi HY. Expression analysis of the ataxin-1 protein in tissue from normal and spinocerebellar atiaxia type 1 individuals. Nature Genet 1995;10:94-98.

32. Silveira l, Lopes-Cendes I, Kish S, Maciel P, Gaspar C, Coutinho P, Botez MI, Teive H, Arruda W, Steiner CE, Pinto-Junior W, Maciel JA, Jain S, Sack, G, Andermann E, Sudarsky L, Rosenberg, R, Macleod P, Chitayat D, Babul R, Sequeiros J, Rouleau GA. Frequency of spinocerebellar ataxia type 1, dentatorubropallidoluysian atrophy and Machado-Joseph disease mutations in a large group of spinocerebellar ataxia patients. Neurology 1996;46:214-218.

33. Stevanin G, Le Guern E, Ravisé, N, Chneiweiss H, Durr A, Cancel G, Vignal A, Boch A-L, Ruberg M, Penet C, Pothin Y, Lagroua I, Haguenau M, Rancurel G, Weissenbach J, Agid Y, Brice A. A third locus for autosomal dominant cerebellar ataxia type 1 maps to chromosome 14q24.3-qter: evidence for the existence of a fourth locus. Am J Hum Genet 1994; 54:1 1-20.

34. Subramony SH. Clinical aspects of hereditary ataxia. In Zoghbi H. Proceedings of Course 419: Clinical Aspects and Molecular Genetics of Hereditary Ataxias. American Academy of Neurology 48 ${ }^{\text {th }}$ Annual Meeting, March 23-30, 1996.

35. Sutherland GR, Richards RI. Simple tandem DNA repeats and human genetic disease. Proc Natl Acad Sci USA 1995;92:3636-3641.

36. Takjyama $Y$, Nishizawa M, Tanaka H, Kawashima S, Sakamoto H, Karube Y, Shimazaki H, Soutorne M, Endo K, Ohta S, Kagawa Y, Kanazawa I, Mizuno Y, Yoshida M, Yuasa T, Horikawa Y, Oyanagi K, Nagai H, Kondo T, Inuzuka T, Onodera $O$. Tsuji S. The gene for Machudo-Joseph disease maps to human chromosome 14q. Nature Genet 1993; 4:300-304.

37. Twells R, Yenchitsomanus P-T, Sirinuvin C, Allotey R, Poungvarin N, Viriyavejukul A, Cemal C, Weber J, Farral M, Rodpraser P, Prayoonwiwat N, Williamson R, Chamberlain S. Autosomal dominant cerebellar ataxia with dementia: evidence for a fourth disease locus. Hum Molec Genet 1994;3:177-180.

38. Twist EC, Casaubon LK, Ruttledge MH, Farrer LA, MacLeod PM, Radvany J, Rosenberg RN, Rouleau GA. Machado Joseph disease maps to the same region of chromosome 14 as the spinocerebellar ataxia type 3 locus. Am J Med Genet $1995 ; 32: 25-31$.

39. Zoghbi HY, Pollack MS, Lyons LA, Ferrell RE, Daiger SP, Beaudet AL. Spinocerebellar ataxia: variable age of onset and linkage to human leukocyte antigen in a large kindred. Ann Neurology 1988;23:580-584. 